\title{
Bacterial Associates Modify Growth Dynamics of the Dinoflagellate Gymnodinium catenatum
}

OPEN ACCESS

Edited by:

Xavier Mayali,

Lawrence Livermore National Laboratory (DOE), USA

Reviewed by:

Tatiana A. Rynearson,

University of Rhode Island, USA

Hongbin Liu,

Hong Kong University of Science

and Technology, Hong Kong

*Correspondence:

Christopher J. S. Bolch

chris.bolch@utas.edu.au

tPresent address:

Thaila A. Bejoy,

School of Public Health, Curtin

University, Bentley, WA, Australia

Specialty section:

This article was submitted to

Aquatic Microbiology,

a section of the journal

Frontiers in Microbiology

Received: 16 February 2016

Accepted: 31 March 2017

Published: 19 April 2017

Citation:

Bolch CJS, Bejoy TA and Green DH

(2017) Bacterial Associates Modify Growth Dynamics of the Dinoflagellate

Gymnodinium catenatum.

Front. Microbiol. 8:670.

doi: 10.3389/fmicb.2017.00670

\author{
Christopher J. S. Bolch ${ }^{1 *}$, Thaila A. Bejoy ${ }^{1+}$ and David H. Green ${ }^{2}$ \\ ${ }^{1}$ Institute for Marine and Antarctic Studies, University of Tasmania, Launceston, TAS, Australia, ${ }^{2}$ Scottish Association for \\ Marine Science, Scottish Marine Institute, Oban, UK
}

Marine phytoplankton cells grow in close association with a complex microbial associate community known to affect the growth, behavior, and physiology of the algal host. The relative scale and importance these effects compared to other major factors governing algal cell growth remain unclear. Using algal-bacteria co-culture models based on the toxic dinoflagellate Gymnodinium catenatum, we tested the hypothesis that associate bacteria exert an independent effect on host algal cell growth. Batch co-cultures of $G$. catenatum were grown under identical environmental conditions with simplified bacterial communities composed of one-, two-, or three-bacterial associates. Modification of the associate community membership and complexity induced up to four-fold changes in dinoflagellate growth rate, equivalent to the effect of a $5^{\circ} \mathrm{C}$ change in temperature or an almost six-fold change in light intensity (20-115 moles photons PAR $\mathrm{m}^{-2} \mathrm{~s}^{-1}$ ). Almost three-fold changes in both stationary phase cell concentration and death rate were also observed. Co-culture with Roseobacter sp. DG874 reduced dinoflagellate exponential growth rate and led to a more rapid death rate compared with mixed associate community controls or co-culture with either Marinobacter sp. DG879, Alcanivorax sp. DG881. In contrast, associate bacteria concentration was positively correlated with dinoflagellate cell concentration during the exponential growth phase, indicating growth was limited by supply of dinoflagellate-derived carbon. Bacterial growth increased rapidly at the onset of declining and stationary phases due to either increasing availability of algal-derived carbon induced by nutrient stress and autolysis, or at mid-log phase in Roseobacter co-cultures potentially due to the onset of bacterial-mediated cell lysis. Co-cultures with the three bacterial associates resulted in dinoflagellate and bacterial growth dynamics very similar to more complex mixed bacterial community controls, suggesting that three-way co-cultures are sufficient to model interaction and growth dynamics of more complex communities. This study demonstrates that algal associate bacteria independently modify the growth of the host cell under non-limiting growth conditions and supports the concept that algal-bacterial interactions are an important structuring mechanism in phytoplankton communities.

Keywords: dinoflagellate, bacteria, interaction, model, Gymnodinium catenatum, growth 


\section{INTRODUCTION}

In natural aquatic systems marine microalgae grow in close association with a complex microbial community (associates) that form an intrinsic component of phytoplankton physiology and ecology (Cole, 1982). Considerable research from a diversity of species indicate that interactions between the associate community and phytoplankton (host) cells are ubiquitous in marine and freshwater systems (Doucette et al., 1998; Amin et al., 2012; Ramanan et al., 2015), play important roles in algal bloom initiation, growth and termination (Azam, 1998; Doucette et al., 1998), and moderate the lifecycle and behavior of algal cells (Adachi et al., 2003; Mayali et al., 2007). Interactions vary from highly specific symbiont/host relationships (e.g., Amin et al., 2015) to commensal/mutualist relationships (e.g., Grossart, 1999; Amin et al., 2009) or parasitic/algicidal behavior (e.g., Fukami et al., 1992; Iwata et al., 2004; Wang et al., 2015), to less-specific interactions such as nutrient competition/modification (Danger et al., 2007). Interactions among associates and the algal host also directly or indirectly alter the behavior, and physiology of both the algal and bacterial partners. For example, phytoplankton stimulate bacteria by supplying much of the organic matter for bacterial growth (e.g., Lau et al., 2007) or produce antibiotics limiting bacterial growth (Cole, 1982). Bacteria produce growth factors such as vitamins and essential nutrients (Croft et al., 2005), increase availability of iron (Amin et al., 2009), or can even modify phycotoxin content and production by diatoms and dinoflagellates (e.g., Osada and Stewart, 1997; Hold et al., 2001; Albinsson et al., 2014).

The composition and structure of associate bacterial communities is broadly similar across different species. For example, among the dinoflagellates, Alphaproteobacteria (Rhodobacteraceae) are the dominant phylotype associated with Pfiesteria sp. (Alavi et al., 2001), Alexandrium tamarense and Scrippsiella trochoidea cultures (Hold et al., 2001). Similarly, members of Gammaproteobacteria belonging to Alteromonadaceae (Marinobacter sp. and Alteromonas sp.) are associated with a wide variety of dinoflagellates (Alavi et al., 2001; Hold et al., 2001; Seibold et al., 2001; Ferrier et al., 2002; Jasti et al., 2005). Despite the similarities, several studies also indicate that phylogenetically related associates of different phytoplankton species are genetically/functionally different and engage in species-specific interactions (Bolch et al., 2004; Green et al., 2006; Amin et al., 2009).

Associate communities of uni-algal cultures are composed of potentially 1000s of bacterial genotypes; even carefully washed and isolated single cells result in non-axenic cultures with upward of 20-50 bacterial types (Alavi et al., 2001; Hold et al., 2001; Green et al., 2010). This diversity results in potentially 1000 s of bacteriabacteria and bacterial-algal interactions that confound controlled experiments to examine interactions. To address this problem we have developed simplified co-culture experimental models for three dinoflagellate genera (Scrippsiella, Lingulodinium, and Gymnodinium) that contain a dinoflagellate host and one to three cultured bacterial associates of the dinoflagellate (Bolch et al., 2011). The models provide not only a tractable tool to investigate mechanisms of interaction, but also enable controlled testing of specific hypotheses to gain insight into the function and importance algal-bacterial interactions in complex natural systems.

Despite evidence from culture-based research and evidence of linkages between bacterioplankton and phytoplankton production in nature (Prieto et al., 2015), we have limited knowledge of the relative scale and importance of microbial effects on phytoplankton growth. Models of phytoplankton growth currently include only bottom-up physical factors of light and temperature (Thompson, 1999), availability and uptake of major ( $\mathrm{C}, \mathrm{N}, \mathrm{P}$, and $\mathrm{Si}$ ) and minor nutrients (Morel and Hudson, 1985), and top-down controls of predation and loss due to sinking (Turner et al., 1998). Here we use the Gymnodinium catenatum co-culture model to examine the relative scale and effect of associate bacteria community membership and complexity on dinoflagellate growth dynamics. Our culture experiments indicate that changes in the bacterioplankton community can be as significant for growth of dinoflagellates as changes induced by seasonal changes in light and temperature.

\section{MATERIALS AND METHODS}

\section{Bacterial Cultures}

Associate bacteria for co-culture experiments were isolated from G. catenatum cultures and characterized as detailed in earlier studies (Green et al., 2004, 2010). Three bacterial associates used for co-culture experiments, Alcanivorax cf. borkumensis DG881, Marinobacter sp. DG879 and Roseobacter sp. DG874, were selected for experiments based on their ability to support G. catenatum growth in uni-bacterial cultures (data not shown). Bacterial cultures were maintained on either Zobell's marine agar (ZM1) prepared in $75 \%$ filtered seawater (26 ppt), or the same medium prepared at $1 / 10$ concentration of nutrients $(Z M / 10)$. ZM1 medium contained $5 \mathrm{~g} \mathrm{~L}^{-1}$ of bacterial peptone, $1 \mathrm{~g} \mathrm{~L}^{-1}$ of yeast extract and was solidified with $15 \mathrm{~g} \mathrm{~L}^{-1}$ of Difco-Bacto ${ }^{\mathrm{TM}}$ Agar. Both media were supplemented with filter-sterilized trace elements and vitamins (Green et al., 2004). The medium was supplemented with $1 \%(\mathrm{w} / \mathrm{v})$ sodium acetate as a carbon source when used for Alcanivorax DG881 (Green et al., 2004).

\section{Establishment of Controlled Associate Co-cultures G. catenatum}

Cultures of $G$. catenatum with specific bacterial associate communities were established following the approach described in detail by Bolch et al. (2011) using resting cysts produced by sexually compatible crosses of G. catenatum strains GCHU11 and GCDE08 (hereafter HU11 and DE08 respectively). Briefly, resting cysts of $G$. catenatum were harvested by centrifugation and surface-sterilized by resuspension in $0.5 \%$ hydrogen peroxide for $1 \mathrm{~h}$. Batches of 30-40 surface-sterile resting cysts were then aseptically transferred to sterile $36 \mathrm{~mm}$ Petri dishes containing $1.9 \mathrm{~mL}$ of sterile GSe algal culture medium, a medium based on sterile natural seawater (28 ppt) supplemented with nitrate, phosphate, trace metals, and vitamins (Blackburn et al., 1989). Associate bacterium additions used in the experiments are shown in Table 1. Cultures of each associate bacterium were grown 
TABLE 1 | Cultures and bacterial additions used to establish controlled bacterial associate communities.

\begin{tabular}{|c|c|}
\hline Culture identifier & Bacterial treatment of resting cysts \\
\hline M & Marinobacter sp. DG879 added to cysts at $10^{5}$ cells $\mathrm{mL}^{-1}$ \\
\hline A & Alcanivorax sp. DG881 added to cysts at $10^{5}$ cells $\mathrm{mL}^{-1}$ \\
\hline $\mathrm{R}$ & Roseobacter sp. DG874 added to cysts at $10^{5}$ cells $\mathrm{mL}^{-1}$ \\
\hline MA & $\begin{array}{l}\text { Marinobacter sp. DG879 and Alcanivorax sp. DG881 in } \\
\text { equal proportions; added to cysts at a total concentration } \\
\text { of } 10^{5} \text { cells } \mathrm{mL}^{-1}\end{array}$ \\
\hline AR & $\begin{array}{l}\text { Alcanivorax sp. DG881 and Roseobacter sp. DG } 874 \text { in } \\
\text { equal proportions; added to cysts at a total concentration } \\
\text { of } 10^{5} \text { cells } \mathrm{mL}^{-1}\end{array}$ \\
\hline MR & $\begin{array}{l}\text { Marinobacter sp. DG879 and Roseobacter sp. DG874 in } \\
\text { equal proportions; added to cysts at a total concentration } \\
\text { of } 10^{5} \text { cells } \mathrm{mL}^{-1}\end{array}$ \\
\hline MAR & $\begin{array}{l}\text { Marinobacter sp. DG879, Alcanivorax sp. DG881 and } \\
\text { Roseobacter sp. DG874 in equal proportions; added to } \\
\text { cysts at a total concentration of } 10^{5} \text { cells } \mathrm{mL}^{-1}\end{array}$ \\
\hline DEHU & $\begin{array}{l}100 \mu \mathrm{L} \text { of } 8 \mu \mathrm{m} \text { filtrate from mid-log phase parent cultures } \\
\text { GCDE08 and GCHU11; added to cysts undiluted }\end{array}$ \\
\hline DE08 & Clonal non-axenic parent strain GCDE08 for comparison \\
\hline HU11 & Clonal non-axenic parent strain GCHU11 for comparison \\
\hline
\end{tabular}

All cultures were established from 30 to 40 surface-sterilized Gymnodinium catenatum resting cysts (GCDE08 × HU11 crosses), germinated and grown for 30 days, transferred to $150 \mathrm{~mL}$ Erlenmeyer flasks prior to growth experiments. All culture treatments carried out in duplicate.

overnight in ZM10 medium (Green et al., 2004) and immediately added to dishes of sterile resting cysts in single, pairwise or threeway combinations at a total bacterial concentration of $10^{5} \mathrm{CFU}$ $\mathrm{mL}^{-1}$. All bacterial additions were established as independent triplicates. Dishes were sealed with parafilm ${ }^{\mathrm{TM}}$ and incubated at $19 \pm 2^{\circ} \mathrm{C}$ at a light intensity of $90 \pm 10 \mu$ moles $\mathrm{m}^{-2} \mathrm{~s}^{-1}$ with a 12L:12D photoperiod to allow for resting cyst germination.

From previous studies (Bolch et al., 2004, 2011; Albinsson et al., 2014), cases of co-culture contamination by non-associate bacteria were detectable during the establishment phase using sterile medium-only controls and in each case resulted from contaminated algal growth medium. To minimize the risk of systematic contamination, all algal culture media was prepared from autoclave-sterilized stock reagents where possible. To control aerial/casual contamination, all co-culture flasks used steristoppers with double-layer foil dust caps and all culture manipulation and transfers were carried out in a class 2 laminar flow cabinet using standard aseptic microbiological techniques. Medium sterility (growth medium only) and cyst sterility controls (cysts with no bacteria added) and mixed parental bacterial community controls were used in all experiments. Sterility controls were assessed for accidental or systematic failure of sterilization or contamination spread plating of multiple undiluted sub-samples onto ZM1 and ZM10 medium (Green et al., 2004). Plates were incubated at $20^{\circ} \mathrm{C}$ for 7 days, assessed for evidence of bacterial growth by direct visual inspection and 5-60x magnification using a Leica Z9.5 stereomicroscope. If contamination was detected in media-only controls then the experiment was terminated and re-established. If contamination was detected in cyst sterility controls, all cultures derived from the contaminated cyst batch were discarded.
All treatments and control dishes containing resting cysts were examined using a Leica Z9.5 stereomicroscope every 3 days after germination. Cyst quality was monitored by recording final germination (\%) and motile dinoflagellate cells by direct examination at 20-63x using a stereomicroscope. After 30 days, two replicates from treatments and positive controls were transferred to sterile $150 \mathrm{~mL}$ Erlenmeyer flasks containing $100 \mathrm{~mL}$ of sterile GSe medium, stoppered with sterile dust caps to limit aerial or other casual contamination, and grown at $19 \pm 2^{\circ} \mathrm{C}$ under a light intensity of $90 \pm 10 \mu$ moles $\mathrm{m}^{-2} \mathrm{~s}^{-1}$ (12L: 12D). Negative control cultures (no added bacteria) resulted in death of G. catenatum after germination (see Bolch et al., 2011) and could not be included in further growth studies.

For growth experiments, the established $100 \mathrm{~mL}$ cultures were aseptically transferred to $150 \mathrm{ml}$ flasks of sterile GSe medium and grown under the light and temperature conditions described above. Dinoflagellate cell concentration was determined every 4 days from triplicate sub-samples using a Sedgwick-Rafter counting chamber (Guillard, 1973) and by in vivo fluorometry (Kiefer, 1973). Bacterial concentration (CFU $\left.\mathrm{mL}^{-1}\right)$ was determined every 4 days from triplicate sub-samples and serial dilution spread-plating (Buck and Cleverdon, 1960) onto ZM1 agar. Colony morphology of the associate bacteria used was not sufficiently distinct for reliable differentiation during cell counts therefore total bacterial community counts were undertaken. Bacterial colony morphology on plates was routinely examined for evidence of contamination by non-associate bacteria.

\section{Statistical Analysis}

Growth phases were derived from visual inspection of growth curves, and exponential growth/death rates calculated according to Guillard (1973). Differences in dinoflagellate exponential growth and death rates, maximum cell concentration (cells $\mathrm{mL}^{-1}$ ) were compared by one-way ANOVA with significant differences determined by Tukey's post hoc tests, using SPSS ver. 19 (LEAD Technologies, Chicago, IL, USA). Overall similarity of dinoflagellate batch culture dynamics was compared by principal component analysis (PCA) using the software package PRIMER 6. Seven variables were derived from growth curves of each replicate culture for each treatment: exponential growth and death rate (Figures 1A,B); maximum cell concentration (Figure 1C); and the duration of four batch culture growth phases indicated in Figures 2, 3. Variables were normalized prior to analysis (subtraction of variable means, division by variable standard deviation) to account for order of magnitude differences in value ranges (Clarke and Gorley, 2006). The correlation matrix was used for a two-dimensional PCA, and the principal components displayed as an ordination plot.

\section{RESULTS}

\section{Germination, Sterility, and Negative Controls}

No culturable bacteria were detected by dilution spread plating of growth media from sterility controls (medium only) and negative 


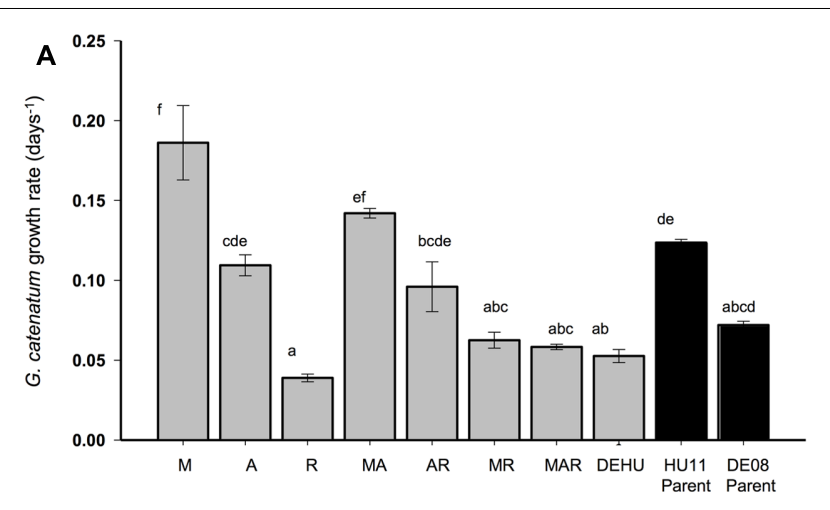

B

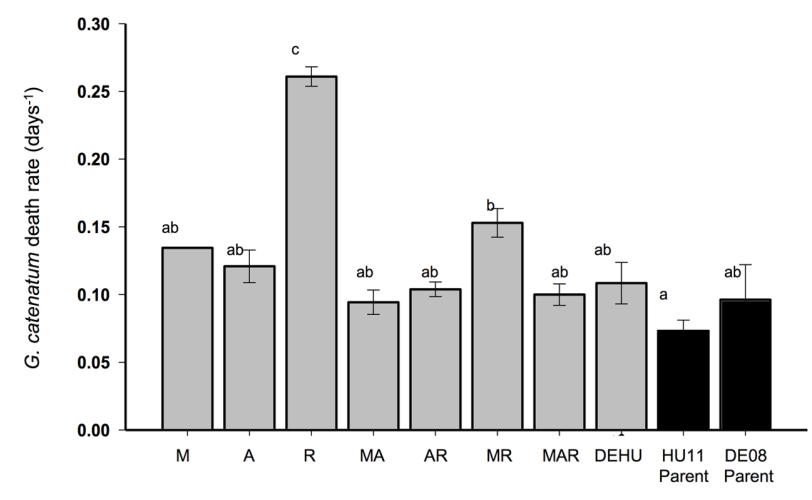

C

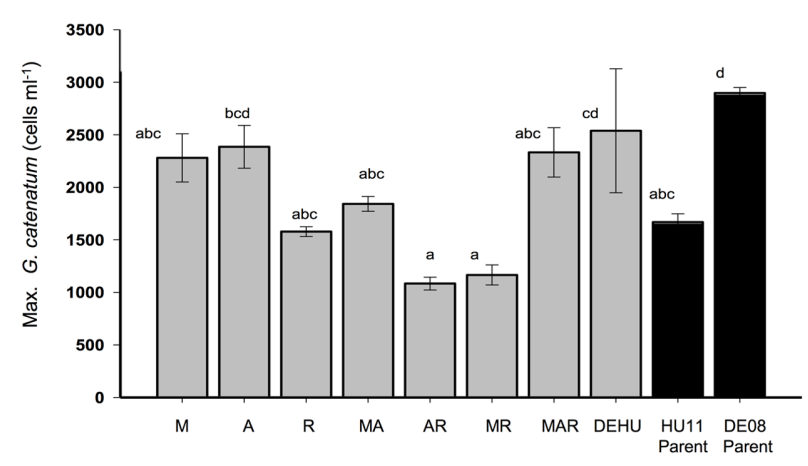

FIGURE 1 | Exponential growth rate (A), death rate (B), and maximum cell density (C) ( \pm SE) of Gymnodinium catenatum cultures grown with single, pairwise and three-way combinations of bacterial associates compared to mixed culture community (DEHU) and parental non-axenic cultures (GCHU11 and GCDE08). M, Marinobacter DG879; A, Alcanivorax DG881; R,

Roseobacter DG874. See Table 1 for culture codes and additional details. Letters $(a-f)$ indicate significant differences $(p=<0.05)$.

controls (cysts with no bacteria added) indicating that surfacesterilization was effective at removing bacteria and there was low probability of incidental or systematic contamination of media or from airborne sources. Negative controls containing cysts with no bacterial addition showed poor germination rates (15\%) and dinoflagellate cells died within the 30 day initial observation period. Long-term culture was not possible and these treatments were not included in the study. All cultures receiving bacterial associate additions exhibited germination rates typical of non-sterilized cysts from earlier studies (54\%, Bolch et al., 2002) and similar to the mixed community positive control (DEHU, $p>0.066$ ) with the exception of reduced germination in uni-bacterial Roseobacter sp. DG874 co-cultures (25\%, $p=0.013)$. No significant difference was observed in dinoflagellate cell number per cyst at day 30 post-germination $(f=4.422 ; \mathrm{df}=8,18 ; p>0.982)$.

\section{Growth Dynamics in Batch Culture}

All controlled associate co-cultures were grown successfully to $150 \mathrm{ml}$ flask scale, aseptically transferred, and grown through an extended batch culture cycle over a period of 68 days. Growth curves and rates derived from cell counts were not substantially different to that calculated from in vivo fluorescence data (not shown). As fluorescence-based estimates are potentially unreliable outside logarithmic-phase (Falkowski and Kiefer, 1985; Cullen et al., 1988), only cell count data were used for further analysis. Presence or concentration of non-cultured bacteria could not be determined in our experiment, however, routine observation of colony morphology on dilution plates did not detect evidence of contamination by culturable non-associate bacteria in experimental cultures.

Marked differences in dinoflagellate growth rate, death rate, maximum cell concentration (Figure 1) and batch culture dynamics were evident between G. catenatum cultures grown with different bacterial associate communities (Figures 2, 3). No distinct lag-phase was evident, but the exponential growth phase was longer and the stationary phase shorter in cultures containing Roseobacter sp., either alone or in combination with other bacteria. Cultures grown with Marinobacter sp. or Alcanivorax sp. exhibited higher exponential growth rates than mixed associate controls $(f=23.99 ; \mathrm{df}=9,10 ; p=0.000,0.033)$ or cultures containing only Roseobacter sp. $(p<0.008)$. Cultures grown with Roseobacter sp. showed the slowest exponential growth rate (Figure 1) and did not reach stationary phase till day 40-44 (Figure 2, R). These co-cultures also exhibited a more rapid decline in death phase than cultures grown with Marinobacter sp. $(f=19.301 ; \mathrm{df}=9,10 ; p=0.001)$ or Alcanivorax sp. $(f=19.301 ; \mathrm{df}=9,10 ; p=0.000)$ (Figure 1).

Co-cultures grown with pair-wise combinations of bacteria exhibited growth curves with a mix of features of the respective uni-bacterial cultures (Figure 2, MA, AR, and MR). Co-cultures with Marinobacter sp. and Alcanivorax sp. showed a short rapid exponential growth period (days 0-12) similar to cultures grown only with Marinobacter sp., but a more gradual death phase similar to co-cultures containing only Alcanivorax sp. Similar "hybrid" growth curves were evident in the cultures grown with both Alcanivorax sp. and Roseobacter sp., however, cultures grown with Marinobacter sp. and Roseobacter sp. showed growth curves similar to co-cultures grown with Roseobacter sp. (compare Figures 2, MR and R). Mean growth rates of pairwise combinations were intermediate between that of the corresponding uni-bacterial cultures in all cases (Figure 1). Mean maximum cell concentrations in two-bacterium co-cultures containing Roseobacter sp. achieved a lower maximum cell concentration than mixed community controls $(f=6.804$; 

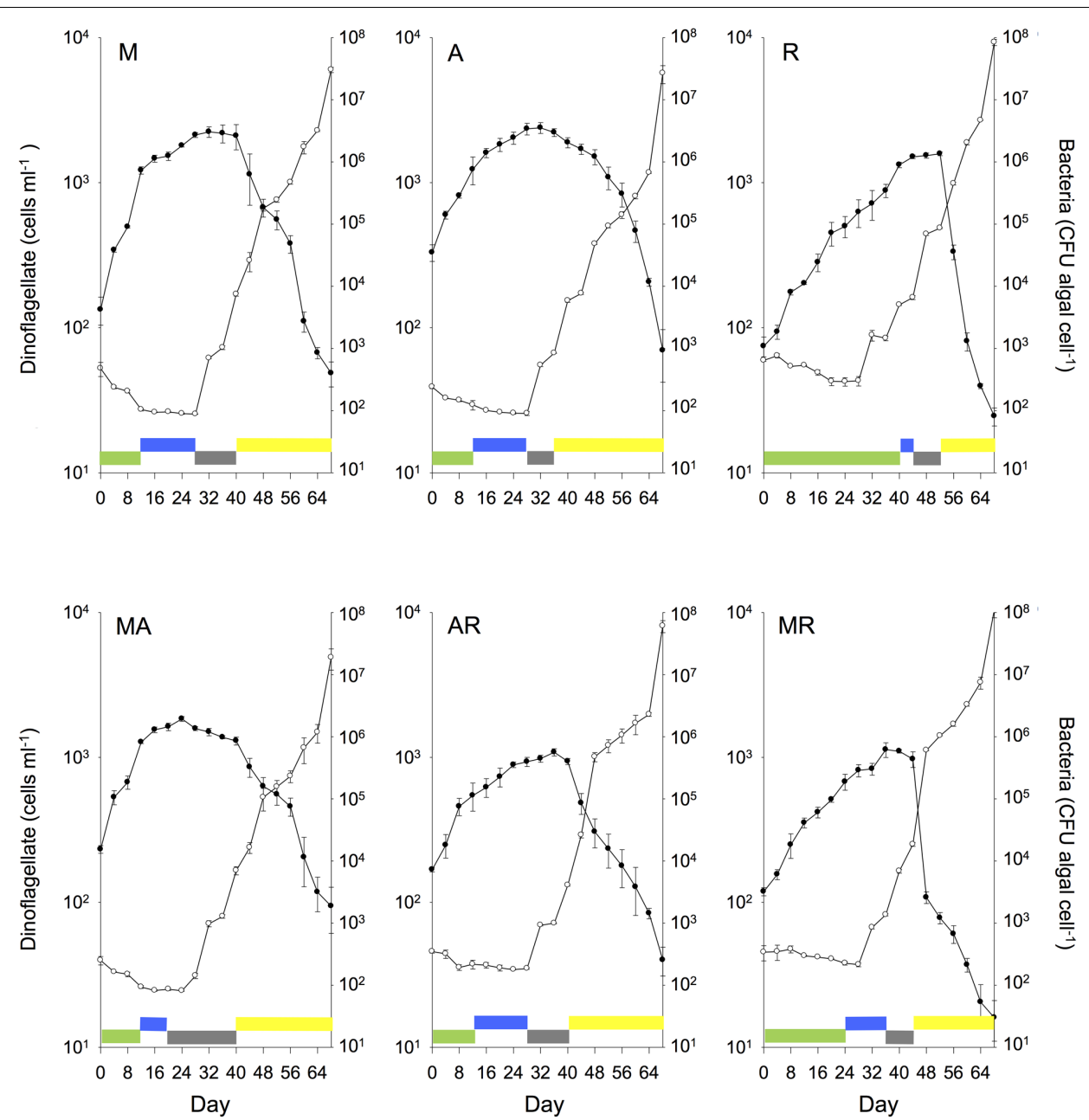

$\begin{array}{ll}\text { Exponential } & \text { Stationary } \\ \text { Declining } & \text { Death }\end{array}$

FIGURE 2 | Mean ( \pm SE) batch culture growth curves of $G$. catenatum (closed circles) and total bacteria (CFU algal cell-1 , open circles) from duplicate cultures grown with single and pairwise combinations of bacterial associates (M, Marinobacter DG879; A, Alcanivorax DG881; R, Roseobacter DG874; MA, Marinobacter DG879 and Alcanivorax DG881; AR, Alcanivorax DG881 and Roseobacter DG874; MR, Marinobacter DG879 and Roseobacter DG874). See Table 1 for culture codes and additional details.

df $=9,10 ; p<0.01)$. A sharp decline after day 44 was evident in cultures grown with Marinobacter sp. and Roseobacter sp., however, the overall rate of decline to day 68 was not different from other two-bacterium combinations.

Cultures grown with communities composed of three bacterial strains (MAR) exhibited batch culture dynamics most similar to those of the mixed associate control (DEHU) containing log-phase bacterial communities from cultures HU11 and DE08 (Figure 3). Exponential growth rate, maximum cell concentration and death rates were almost identical (Figure 1) and only small differences were noted in the onset and length of batch culture phases (see Figures 2, 3). The three-way combination cultures (MAR) exhibited a lower exponential growth rate $(f=23.99 ; \mathrm{df}=9,10 ; p=0.041)$ than either parent crossing strain DE08 and or HU11 (Figure 1).
The two-dimensional PCA of dinoflagellate growth curve parameters separated cultures grown with Roseobacter sp. versus Alcanivorax sp. and Marinobacter sp. along the PC1 axis, primarily due to increased exponential phase duration and increased death rate (Figure 4). Pairwise combinations of associates were placed midway between the relevant two uni-bacterial associate cultures. Cultures grown with a threeway associate combination (MAR) and mixed parental associate communities (DEHU) were displaced negatively along the PC2 axis, primarily due to higher maximum cell concentrations and an extended duration of death phase.

\section{Bacterial Abundance and Growth}

Similar patterns of bacterial abundance were observed across all cultures. Bacteria per dinoflagellate cell (CFU dinoflagellate 

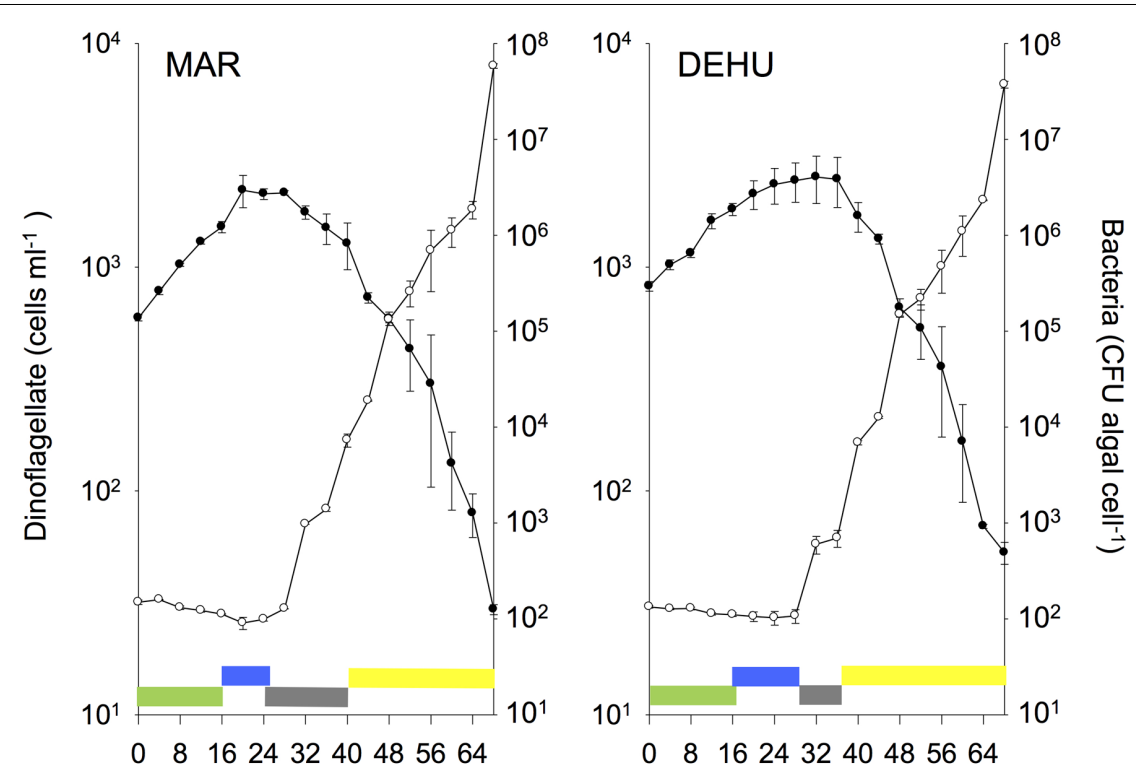

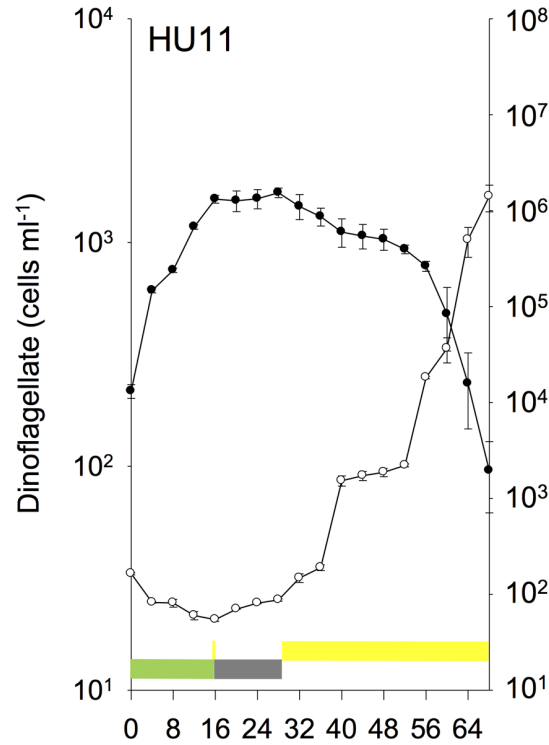

Day

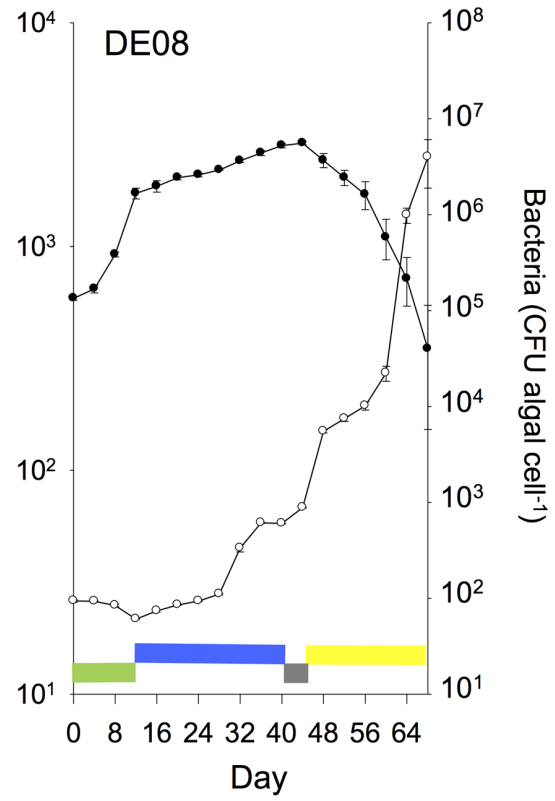

Stationary

Death

FIGURE 3 | Mean ( \pm SE) batch culture growth curves of G. catenatum (closed circles) and total bacteria (CFU algal cell ${ }^{-1}$, open circles) from duplicate cultures grown with three-way combinations of bacterial associates compared to mixed culture community co-cultures and parent cultures (MAR, Marinobacter DG879, Alcanivorax DG881 and Roseobacter DG874; DEHU, mixed bacterial community from non-axenic GCHU11 and GCDE08 parent cultures; GCDE08, GCHU11, clonal non-axenic parent cultures). See Table 1 for culture codes and additional details.

cell $^{-1}$ ), remained relatively constant during dinoflagellate exponential phase in most cultures, beginning between 100 and 200 bacteria cell $^{-1}$, decreasing to approximately 100 bacteria cell ${ }^{-1}$ by day $24-28$ in most cases (see Figures 2, 3). Bacteria increased sharply at or near the end of dinoflagellate logarithmic-phase to approximately $10^{7}-10^{8}$ bacteria cell $^{-1}$ by day 68 when the experiment was terminated.

Changes in bacterial versus dinoflagellate abundance were strongly associated with dinoflagellate growth phase (Figures 5, 6) and followed similar trajectories over the 


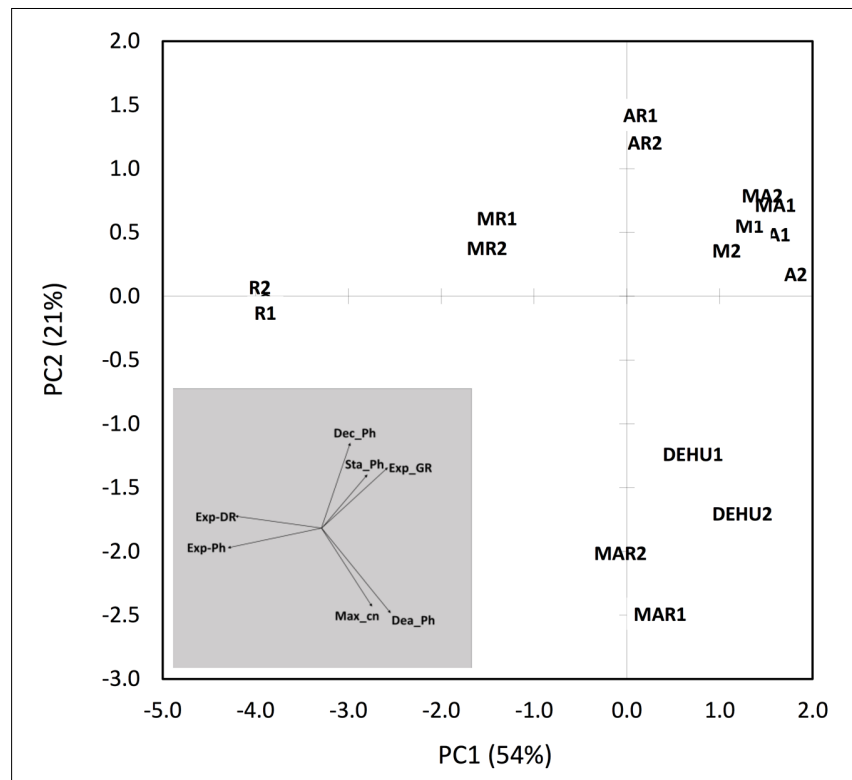

FIGURE 4 | Two-dimensional principal component analysis (PCA) of dinoflagellate batch growth dynamics of G. catenatum cultures grown with different associate bacterial communities. Variables were

normalized prior to analysis and included exponential growth and death rate, maximum cell concentration, and batch growth phase durations indicated by colored bars in Figures 2, 3. Replicate co-cultures are indicated by number suffix (1 or 2). See Table 1 for culture codes and additional detail (M, Marinobacter DG879; A, Alcanivorax DG881; R, Roseobacter DG874; MA, Marinobacter DG879 and Alcanivorax DG881; AR, Alcanivorax DG881 and Roseobacter DG874; MR, Marinobacter DG879 and Roseobacter DG874; MAR, Marinobacter DG879, Alcanivorax DG881 and Roseobacter DG874; DEHU, mixed bacterial community from non-axenic GCHU11 and GCDE08 parent cultures). Vectors of original batch curve variables used in the analysis are shown in the shaded plot. Variables: Dea_Ph, length of death phase in days; Dec_Ph, length of declining phase in days; Exp_DR, death rate $(\mu)$ during death phase; Exp_GR, growth rate $(\mu)$ during log-phase; Exp_Ph, length of dinoflagellate log-phase in days; Max_cn, maximum dinoflagellate cell concentration (cells $\mathrm{ml}^{-1}$ ); Sta_Ph, length of stationary phase in days.

course of the experiment (Figure 5A). Bacterial abundance increased with dinoflagellate concentration during dinoflagellate exponential phase, increased rapidly during dinoflagellate stationary phase, and remaining high during culture death phase. Mean abundance patterns differed among treatments, most evident when comparing parental cultures GCDE08 and GCHU11 with the mixed community control (DEHU) and the three-way combination of associates (MAR) which exhibited a similar intermediate microbial-dinoflagellate abundance pattern (Figure 5B). Total bacterial community growth rate ranged from 0.03 to 0.075 days $^{-1}$ during dinoflagellate exponential phase and was positively correlated with dinoflagellate growth rate $\left(r^{2}=0.46\right.$, df $=18, p<0.001$; Figure 6). From day 28 , total bacterial growth rate increased dramatically in all cultures (0.16-0.23 days $\left.{ }^{-1}\right)$, coinciding with onset of stationary phase except in co-cultures with Roseobacter sp. and two-way co-cultures containing Marinobacter sp. and Roseobacter sp. where increased bacterial growth rate coincided with mid- and late-log to declining phase respectively.
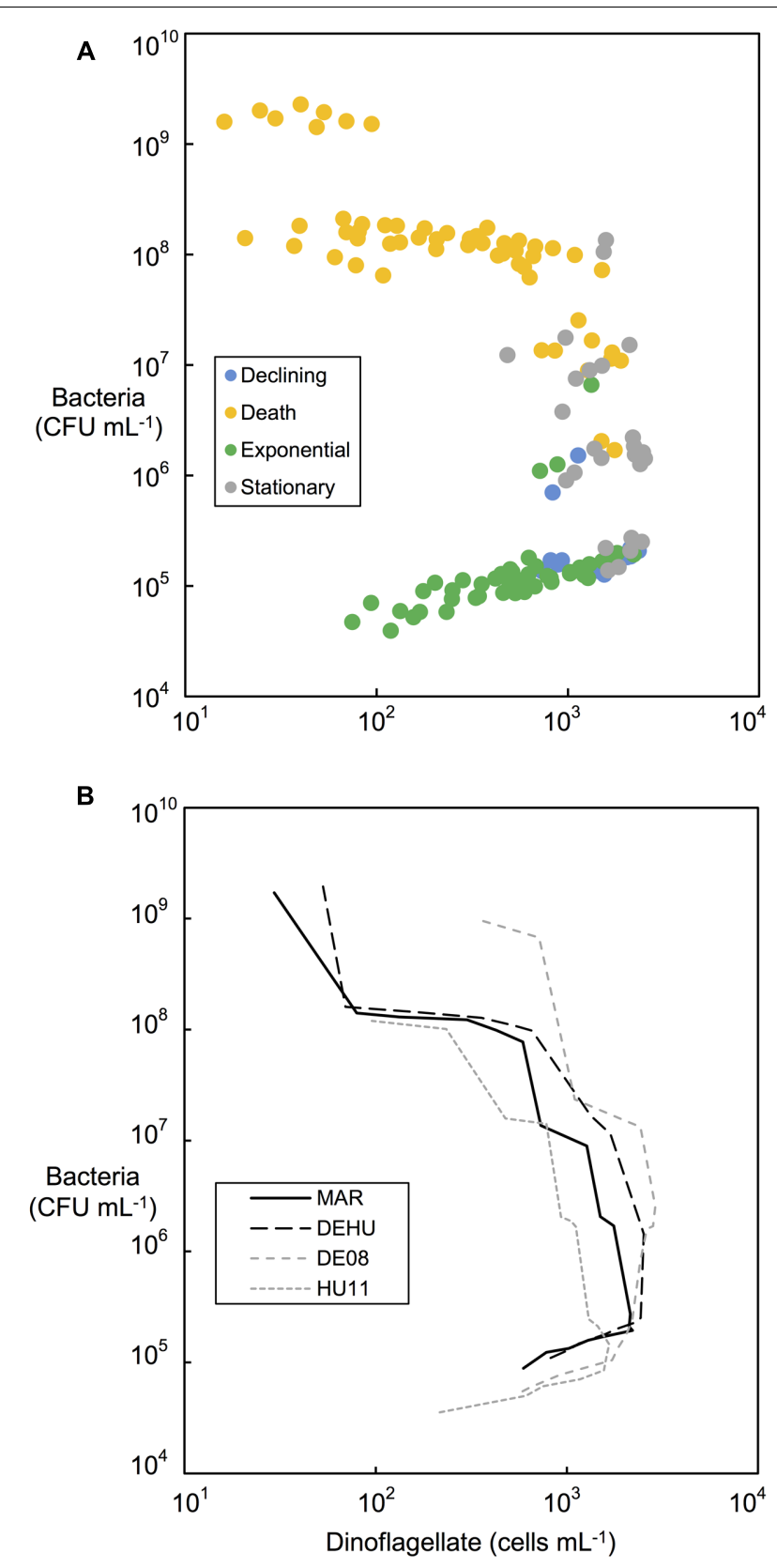

FIGURE 5 | Bacterial and dinoflagellate cell concentrations (cells $\mathrm{mL}^{-1}$ ) during different phases of dinoflagellate culture growth. (A) All replicate controlled associate community cultures categorized according to dinoflagellate growth phases indicated by colored bars in Figures 2, 3. (B) Comparison of mean bacterial and dinoflagellate concentrations from replicate cultures $(n=2)$ of three-way combination (MAR) compared to a mixed community (DEHU) and each parental non-axenic culture (GCDE08 and GCHU11). See Table 1 for culture codes and additional detail.

\section{DISCUSSION}

Our experiments demonstrate that associate bacterial communities modify dinoflagellate growth independent of 


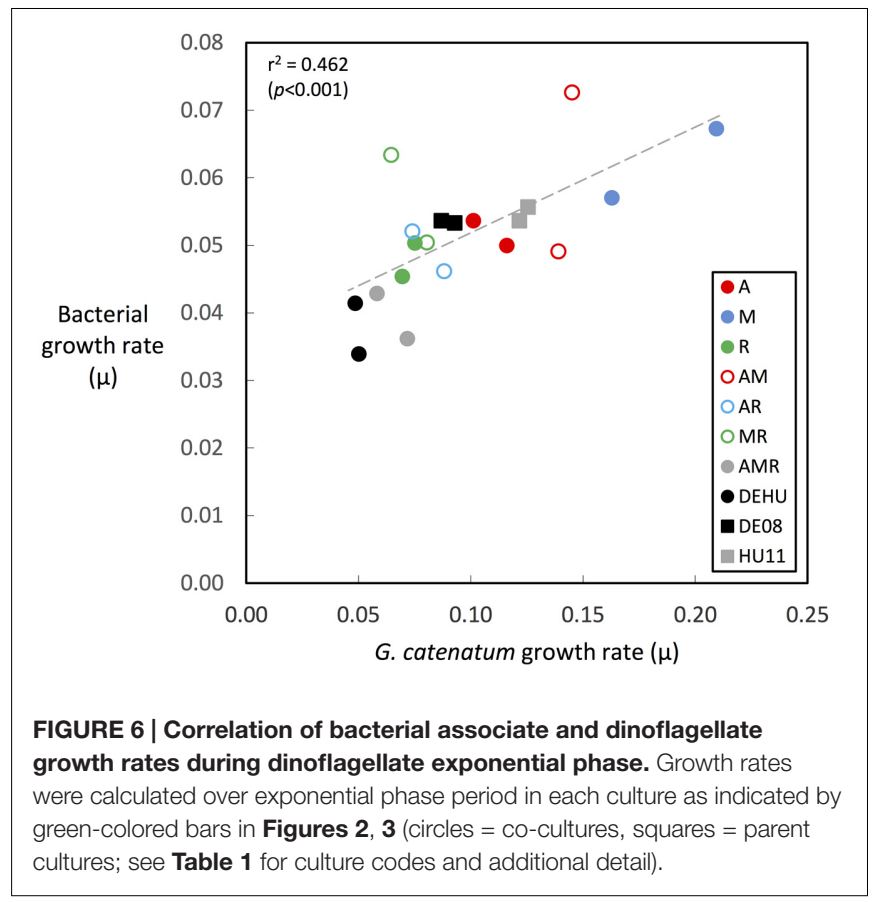

other environmental factors considered to control growth of phytoplankton. Co-cultures were grown under identical conditions, in nutrient-replete medium (including vitamins) at saturating light intensity (90-100 $\mu$ moles photons PAR $\mathrm{m}^{-2} \mathrm{~s}^{-1}$ at $19^{\circ} \mathrm{C}$; Armstrong, 2010), and in the middle of the optimal temperature for $G$. catenatum in both lab culture $\left(12-25^{\circ} \mathrm{C}\right.$; Blackburn et al., 1989) and nature $\left(12-20^{\circ} \mathrm{C}\right.$; Hallegraeff et al., 2012). The significant observed differences in algal growth dynamics support the concept that the associate bacterial interactions are an important factor in algal population dynamics even under optimal and non-limiting conditions. The scale of change in growth rates was surprisingly large ( $>$ four-fold) and equivalent to that typically observed for G. catenatum over a five degree temperature range, or an almost six-fold increase/decrease in light intensity (Figure 7). Environmental changes of this magnitude are of similar scale to those experienced over an annual cycle in mid-latitude coastal waters of southern Tasmania where G. catenatum forms seasonal bloom populations (Hallegraeff et al., 2012), indicating that the influence of bacterial associates is potentially as important for G. catenatum population dynamics as light and temperature.

Changes in phytoplankton growth due to modification of bacterial communities are described from a range of phytoplankton species. For example, co-culture with a Flavobacterium increases maximum cell density, growth rate and length of stationary phase of axenic cultures of the diatom, Chaetoceros gracilis, and haptophytes Isochrysis galbana and Pavlova lutheri (Suminto and Hirayama, 1997). Harvestable biomass of the green alga Botryococcus braunii increases by $50 \%$ when grown in co-culture with a cultured alphaproteobacterial associate (Tanabe et al., 2015). Supplementation with four different associates resulted in a doubling of growth rate and
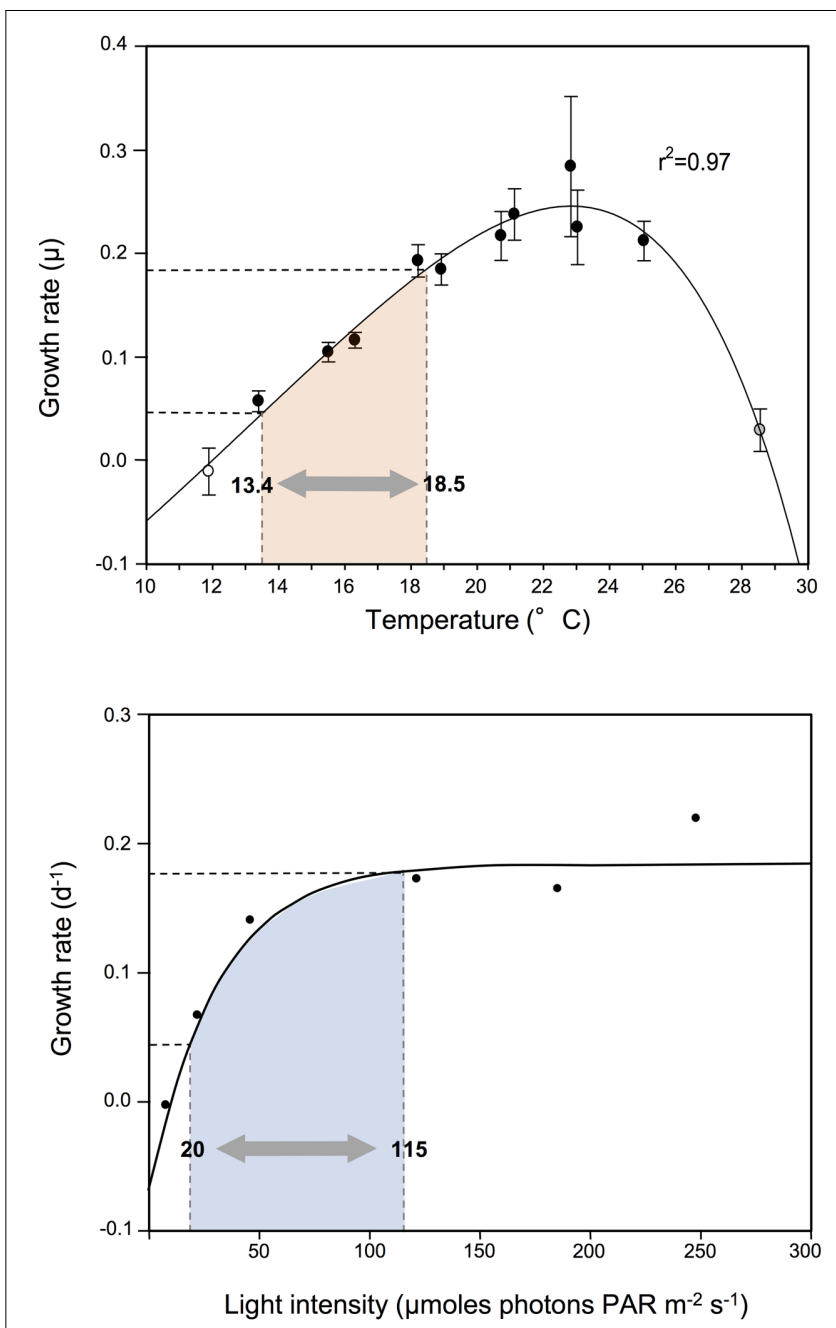

FIGURE 7 | Changes in exponential growth rate of G. catenatum strains due to modified associate bacteria compared to responses to light and temperature. Range of growth rate change observed due to associate microbial indicated by shaded area within dashed lines; equivalent temperature and light ranges shaded in pink and blue respectively. Temperature and light response of $\mathrm{G}$. catenatum at $19^{\circ} \mathrm{C}$ (equivalent to the present study) were adapted from Armstrong (2010).

an almost three-fold increase in biomass of Chlorella vulgaris (Cho et al., 2015). These findings indicate that bacterial associate interactions are likely to be important for most phytoplankton species.

We observed significant changes in batch culture dynamics, included changes in stationary phase length and cell concentration, and substantial changes in death rate, particularly evident in co-culture with Roseobacter sp. DG874. In particular Roseobacter co-cultures differed in exhibiting rapidly increasing bacterial concentration from mid-log phase rather than at the onset of stationary phase. The underlying cause or mechanism driving the different growth dynamics is difficult to determine from our data. It may be caused by G. catenatum autolysis, or nutrient competition (Wheeler and Kirchman, 1986; 
Jumars et al., 1989), or alternatively, it may result from a Jekylland Hyde interaction where the associate bacterium switches from supportive to algicidal (Seyedsayamdost et al., 2011). Members of the Roseobacter clade often dominate the microbial communities associated with phytoplankton and are known to switch from growth promotion to algilytic activity (Geng and Belas, 2010). For example, Phaeobacter gallaceiencis produces selective, potent algicides roeseobacticide $\mathrm{A}$ and $\mathrm{B}$ that lyse Emiliania huxleyi (Seyedsayamdost et al., 2011), and Dinoroseobacter shibae exhibits similar supportive/algicidal behavior in co-culture with Prorocentrum minimum (Wang et al., 2014). The Roseobacter in our experiments may also switch to algicidal mode during log-phase dinoflagellate growth, resulting in increased cell lysis that counteracts growth from cell division. This would explain the reduction in net growth rate during mid-log phase and ultimately the 1.5 -fold reduction in dinoflagellate concentration at stationary phase. In our models, the mid-log reduction in dinoflagellate growth becomes evident at Roseobacter concentrations of $1.5 \times 10^{5}$ cells $\mathrm{ml}^{-1}$ (day 20-24), much lower than onset of lysis by D. shibae in co-culture models of P. minimum (Wang et al., 2014). However, massive cell lysis and steep death phase occurs at similar Roseobacter sp. concentrations $\left(10^{8}\right.$ cells $\mathrm{ml}^{-1}$ ) to that observed in the Prorocentrum/D. shibae model. Alternatively, the reduction in net-growth rate may be entirely due to G. catenatum autolysis (Berges and Falkowski, 1998). The dinoflagellate cannot be grown axenically (Bolch et al., 2011) so we cannot easily determine the extent of autolysis in the absence of bacteria, however there is little evidence of reduced dinoflagellate net growth rate in co-cultures without Roseobacter sp., suggesting that autolysis is not the main cause.

Similar promotion/lysis patterns were observed in uni- and mixed-bacterial co-cultures with Marinobacter and Alcanivorax, however dinoflagellate lysis and decline occurred on or after declining growth phase. In these cultures, cell lysis was more probably stimulated by cell autolysis caused by onset of nutrient stress (Veldhuis et al., 2001) with bacterial algilytic activity perhaps contributing during the subsequent death phase. Previous studies indicate that algicidal activity is cell densitydependent and may be mediated by acetylated homoserine lactones (AHL)-dependent quorum-sensing mechanisms (Paul and Pohnert, 2011; Egan et al., 2013) that up-regulate algilytic compound pathways. Our preliminary analyses of Marinobacter genome data indicate that most strains produce either short (C4) or medium (C6-8) AHLs but do not possess a conventional quorum-sensing system (Green, unpublished data). However, it is also possible that algilytic activity is be mediated via other quorum-sensing systems (Bassler, 1999).

We practiced rigorous media preparation processes, careful aseptic technique and sub-sampling to minimize risk of subsequent aerial or other contamination. We did not detect random or systematic contamination of the experiment by culturable non-associate bacteria, but we cannot rule out the presence of uncultured bacteria in our co-cultures. However, the consistency of replicates and clear differences between the associate treatments suggest that if present the effect of uncultured bacteria was either not significant or consistent across the experiment. Studies using the same models/methods described here (Bolch et al., 2004, 2011) indicate that rare instances of co-culture contamination are detectable during the germination and establishment phase and the cultures removed from further experimentation. These studies also cultured associate communities at the end-point of the experiments. Sequencing $16 \mathrm{~S}$ rDNA of randomly selected isolates routinely recovered only the expected added associates (Bolch et al., 2011).

While G. catenatum is considered autotrophic, mixotrophy appears common among photosynthetic dinoflagellates (Jeong et al., 2005) and both intracellular bacteria and bacterial uptake has been reported for this species (Seong et al., 2006). However, bacterial ingestion is estimated to contribute less than $2 \%$ to total carbon acquisition by dinoflagellates of similar size to G. catenatum (Seong et al., 2006) and is unlikely to have contributed significantly to growth in our co-culture models. Additionally, capacity to support growth in uni-bacterial cultures is limited to only a few bacterial associates and is highly strain/species specific (Bolch et al., 2004). Even closely related bacterial associates to those used here $(<0.5 \%$ seq. divergence at the $16 \mathrm{~S} \mathrm{rDNA}$ ) are unable to support growth in uni-bacterial co-culture (Bolch et al., 2004). Bacterivory cannot explain this high level of specificity. Other experiments indicate that after germination, G. catenatum growth can be maintained without bacterial associates at similar growth rates by repeated addition $0.2 \mu \mathrm{m}$ filtrates from non-axenic log-phase G. catenatum cultures (Matsumoto and Bolch, unpublished data). Yet removal of associates from late-log phase co-cultures using antibiotics leads to cessation of growth and ultimately death of the dinoflagellate culture (Bolch et al., 2011). Taken together, these observations indicate that the essential growth factor/s are dissolved or colloidal extracellular products produced by associate bacteria.

The consistent patterns of total bacterial and dinoflagellate concentration, the low bacterial growth rates observed, and the correlated growth rates during dinoflagellate exponential phase indicate that bacterial associate growth was limited by algal-derived organic carbon in our models. During exponential growth, phytoplankton tend to release only a few percent of their photosynthetic products directly (Wiebe and Pomeroy, 1999) therefore supply of organic carbon would logically limit bacterial growth in the co-culture models. This is supported by the low bacterial growth rates we observed during dinoflagellate exponential phase $\left(<0.1 \mathrm{day}^{-1}\right)$ which are $1-2$ orders of magnitude lower than associate bacterial taxa grown in organically enriched medium (3.6-8.0 day ${ }^{-1}$ for Marinobacter spp.; Guo et al., 2007). Even the fastest bacterial community growth rates observed during dinoflagellate stationary/death phase (0.36-0.42 $\left.\mathrm{day}^{-1}\right)$ are at least 10-fold less, suggesting that organic carbon limits associate growth throughout the batch growth cycle.

The uncoupling of bacterial and dinoflagellate growth rates during dinoflagellate stationary and death phases is likely due to onset of algal cell autolysis, resulting in increased supply of organic carbon for bacterial growth and perhaps increased bacterial competition for inorganic nutrients 
(Bratbak and Thingstad, 1985), further hastening the decline of the dinoflagellate. The stepwise increases in bacterial abundance during these phases have been noted in earlier studies (Bolch et al., 2011) and results from the use of a 12:12 day night cycle which induces synchronous cell division in G. catenatum ranging from 4 to 13 days $\operatorname{div}^{-1}$ across our experiment. When combined with a 4 day sampling frequency, bacterial growth proceeds in most cultures as a series of rapid increases during/after each semi-synchronous dinoflagellate division. We hypothesize that each division results in quantum increases in host dinoflagellate biomass and exuded organic carbon, which in turn provides substrate for short periods of unconstrained bacterial growth until organic carbon limitation is re-established. The stepwise patterns of total bacterial growth were also remarkably consistent in uni-bacterial and two- and three-way combination models, indicating the same organic carbon limitations and dynamics govern patterns of total abundance of more complex associate communities. We did not track abundance of each bacterial type or assess unculturable bacteria, but other experiments indicate that associates dynamics and behavior in two-way co-culture models can be quite complex. Both the relative proportions of each associate and attachment to algal cell surfaces change markedly over the dinoflagellate growth cycle (Albinsson et al., unpublished), and different associates may interact in different ways during different dinoflagellate growth phases.

Our two- and three-way combination models generally displayed dinoflagellate and bacterial dynamics intermediate of the respective uni-bacterial co-cultures (Figure 4). Increasing associate community complexity to three bacteria resulted in dinoflagellate growth dynamics very similar to the more complex mixed-associate controls (DEHU), indicating that our three-way model is sufficient to model interaction and growth dynamics of more complex associate communities. Interestingly, onset of rapid bacterial growth in our MAR co-cultures only occurred in stationary phase, suggesting that the presence of both Marinobacter and Alcanivorax may moderate the proposed lytic effects of Roseobacter sp. DG874. Similar antagonistic interactions among culture associates protect the dinoflagellate Karenia brevis from lysis by an algicidal Bacteroidetes bacterium, either through release of specific antibiotic activity, or resource competition stopping the bacterium achieving sufficient concentration for lytic activity (Mayali and Doucette, 2002).

Our previous studies show that Roseobacter (including DG874) dominate (85\%) the associate community of GCDE08, with Marinobacter as sub-dominant (13\%) and Alcanivorax being relatively uncommon $(<1 \%)$ (Green et al., 2010). The Roseobacter-dominated community may thus explain the distinctive two-phase exponential growth pattern of GCDE08 cultures, also evident to varying degree in other Roseobacter co-cultures in this work (Figures 2, 3; AR and MR). By logical extension, differing associate community composition may also explain a component of within-species variation in growth/performance commonly observed in algal culture studies. Such observations are usually explained as genetic diversity or uncontrolled/random variance, however, our model indicates that Roseobacter dominated associate communities can lead to reduced growth rate and culture yield. The averaging effect seen in combined co-cultures suggest associate-related effects may be moderated when there is sufficient associate diversity/redundancy, but standard phytoplankton isolation techniques involve several cell-washing steps that reduce associate community diversity. As an example, the total number of associate taxa in parent G. catenatum cultures in our models differ substantially; seven associate taxa in strain GCHU11 versus 17 in GCDE08 (Green et al., 2010). This is sufficiently low for associate effects to be a significant contributor to strain variation and a confounding factor in culture-based algal growth studies.

The importance and contribution of microbial interactions in phytoplankton population decline and nutrient cycling have been recognized for some time but our study shows that associate microbial interactions are of potential equal importance to the physical factors traditionally thought to moderate phytoplankton growth and primary production in the world's aquatic ecosystems. Studies of coastal plankton communities have recently shown that phytoplankton production is reliant on a metabolically active heterotrophic bacterial community even when sufficient inorganic nutrients are available for growth (Prieto et al., 2015), demonstrating that the bacterioplankton can be essential for phytoplankton production in nature. Culturebased studies with models like those used here describe a range of mechanisms that may mediate these processes. For example, a metabolically active bacterioplankton community may be essential for phytoplankton trace metal uptake via an interaction process known as Iron-Carbon mutualism (Amin et al., 2009). Algal-associates of the genus Marinobacter produce the photo-labile iron siderophore, Vibrioferrin (VF), that is released into the algal cell boundary layer. Photolysis of VF leads to release of soluble $\mathrm{Fe}^{3+}$ near the algal cell surface that is rapidly taken up by the algal cell, increasing algal iron uptake rate by almost 20-fold (Amin et al., 2009). The capacity for photo-labile siderophore production is widespread in the natural marine bacterial populations, but estimated to be present in perhaps only $1-2 \%$ of the total microbial community (Gardes et al., 2013), as one might expect if this capacity is associated predominantly with the low abundance algal-associate community. The challenge is now to understand the specific conditions under which these interactive mechanisms alter/modify growth and primary production, and the level of functional redundancy that exists in both the associate and background free-living bacterial communities.

\section{AUTHOR CONTRIBUTIONS}

Authors CB and DG were responsible for the concepts and experimental plan, design of experiments, and the provision of research material including isolation of bacterial strains, and supply of algal strains for the study. Experimental data collection, and analysis was carried out by TB and CB. Drafts of the manuscript, figures and tables were completed by $\mathrm{TB}$ with input 
from $\mathrm{CB}$. The final manuscript and figures were revised by $\mathrm{CB}$ with input from DG.

\section{FUNDING}

This work was supported by University of Tasmania Internal Research Grant Scheme B0015641 awarded to CB.

\section{REFERENCES}

Adachi, M., Kanno, T., Okamoto, R., Itakura, S., Yamaguchi, M., and Nishijima, T. (2003). Population structure of Alexandrium (Dinophyceae) cyst formationpromoting bacteria in Hiroshima Bay, Japan. Appl. Environ. Microbiol. 69, 6560-6568. doi: 10.1128/AEM.69.11.6560-6568.2003

Alavi, M., Miller, T., Erlandson, K., Schneider, R., and Belas, R. (2001). Bacterial community associated with Pfiesteria-like dinoflagellate cultures. Environ. Microbiol. 3, 380-396. doi: 10.1046/j.1462-2920.2001.00207.x

Albinsson, M. A., Negri, A. P., Blackburn, S. I., and Bolch, C. J. S. (2014). Microbial influences on the toxicity of the dinoflagellate Gymnodinium catenatum. PLoS ONE 9:e104623. doi: 10.1371/journal.pone.0104623

Amin, S. A., Green, D. H., Hart, M. C., Küpper, F. C., Sunda, W. G., and Carrano, C. J. (2009). Photolysis of iron-siderophore chelates promotes bacterial-algal mutualism. Proc. Natl. Acad. Sci. U.S.A. 106, 17071-17076. doi: 10.1073/pnas. 0905512106

Amin, S. A., Hmelo, L. R., van Tol, H. M., Durham, B. P., Carlson, L. T., Heal, K. R., et al. (2015). Interaction and signalling between a cosmopolitan phytoplankton and associated bacteria. Nature 522, 98-101. doi: 10.1038/nature14488

Amin, S. A., Parker, M. S., and Armbrust, E. V. (2012). Interactions between diatoms and bacteria. Microbiol. Mol. Biol. Rev. 76, 667-684. doi: 10.1128/ MMBR.00007-12

Armstrong, P. B. (2010). Nitrogen Uptake by Phytoplankton in the Huon Estuary: With Special Reference to the Physiology of the Toxic Dinoflagellate Gymnodinium catenatum. Ph.D. thesis, University of Tasmania, Hobart TAS.

Azam, F. (1998). Microbial control of oceanic carbon flux: the plot thickens. Science 280, 694-696. doi: 10.1126/science.280.5364.694

Bassler, B. L. (1999). How bacteria talk to each other: regulation of gene expression by quorum sensing. Curr. Opin. Microbiol. 2, 582-587. doi: 10.1016/S13695274(99)00025-9

Berges, J. A., and Falkowski, P. G. (1998). Physiological stress and cell death in marine phytoplankton: induction of proteases in response to nitrogen and light limitation. Limnol. Oceanogr. 43, 129-135. doi: 10.4319/lo.1998.43. 1.0129

Blackburn, S. I., Hallegraeff, G. M., and Bolch, C. J. (1989). Vegetative reproduction and sexual life cycle of the toxic dinoflagellate Gymnodinium catenatum from Tasmania, Australia. J. Phycol. 25, 577-590. doi: 10.1111/j.1529-8817.1989. tb00264.x

Bolch, C. J., Negri, A. P., Blackburn, S. I., and Green, D. H. (2002). "Lifecycle variation in PST content and cell toxicity in PST-producing dinoflagellates," in Proceedings of the Life History of Microalgal Species Causing Harmful Blooms: Report of a European Workshop, eds E. Garcés, A. Zingone, M. Montresor, B. Reguera, and B. Dale (Brussels: European Commission), 37-42.

Bolch, C. J. S., Subramanian, T., and Green, D. H. (2011). The toxic dinoflagellate Gymnodinium catenatum (Dinophyceae) requires marine bacteria for growth. J. Phycol. 47, 1009-1022. doi: 10.1111/j.1529-8817.2011.01043.x

Bolch, C. J. S., Vincent, B., Blackburn, S. I., and Green, D. H. (2004). "Hostsymbiont range of growth stimulating bacteria associated with Gymnodinium catenatum," in Proceedings of the Abstract and Programme of the 11th International Conference on Harmful Algae, Capetown.

Bratbak, G., and Thingstad, T. F. (1985). Phytoplankton-bacteria interactions: an apparent paradox? Analysis of a model system with both competition and commensalism. Mar. Ecol. Prog. Ser. 25, 23-30. doi: 10.3354/meps025023

Buck, J. D., and Cleverdon, R. C. (1960). The spread plate as a method for the enumeration of marine bacteria. Limnol. Oceanogr. 5, 78-80. doi: 10.4319/lo. 1960.5.1.0078

\section{ACKNOWLEDGMENTS}

The authors thank Dr. Susan Blackburn (CSIRO Marine and Atmospheric Research) for providing G. catenatum cultures GCHU11 and GCDE08. The authors also thank Prof. Rosa Martinez (University of Cantabria, Spain) for helpful comments on early drafts of this manuscript. We also thank the reviewers for numerous valuable suggestions to improve the manuscript.

Cho, D.-H., Ramanan, R., Jina Heo, J., Lee, J., Kim, B.-H., Oh, H.-M., et al. (2015). Enhancing microalgal biomass productivity by engineering a microalgal bacterial community. Bioresour. Technol. 175, 578-585. doi: 10.1016/j.biortech. 2014.10.159)

Clarke, R. N., and Gorley, R. N. (2006). PRIMER v6. Plymouth: Plymouth Marine Laboratory, 190.

Cole, J. J. (1982). Interactions between bacteria and algae in aquatic ecosystems. Annu. Rev. Ecol. Syst. 13, 291-314. doi: 10.1146/annurev.es.13.110182.001451

Croft, M. T., Lawrence, A. D., Raux-Deery, E., Warren, M. J., and Smith, A. G. (2005). Algae acquire vitamin B12 through a symbiotic relationship with bacteria. Nature 438, 90-93. doi: 10.1038/nature 04056

Cullen, J. J., Yentsch, C. M., Cuccr, T. L., and MacIntyre, H. L. (1988). Autofluorescence and other optical properties as tools in biological oceanography. SPIE 925, 149-156.

Danger, M., Oumarou, C., Benest, D., and Lacroix, G. (2007). Bacteria can control stoichiometry and nutrient limitation of phytoplankton. Funct. Ecol. 21, 202-210. doi: 10.1111/j.1365-2435.2006.01222.x

Doucette, G. J., Kodama, M., Franca, S., and Gallacher, S. (1998). "Bacterial interactions with harmful algal bloom species: bloom ecology, toxigenesis, and cytology," in Physiological Ecology of Harmful Algal Blooms, eds D. M. Anderson, A. D. Cembella, and G. M. Hallegraeff (Berlin: Springer-Verlag), 619.

Egan, S., Harder, T., Burke, C., Steinberg, P., Kjelleberg, S., and Thomas, T. (2013). The seaweed holobiont: understanding seaweed-bacteria interactions. FEMS Microbiol. Rev. 37, 462-476. doi: 10.1111/1574-6976.12011

Falkowski, P., and Kiefer, D. A. (1985). Chlorophyll a fluorescence in phytoplankton: relationship to photosynthesis and biomass. J. Plankton Res. 7, 715-731. doi: 10.1093/plankt/7.5.715

Ferrier, M., Martin, J. L., and Rooney-Varga, J. N. (2002). Stimulation of Alexandrium fundyense growth by bacterial assemblages from the Bay of Fundy. J. Appl. Microbiol. 92, 706-716. doi: 10.1046/j.1365-2672.2002.01576.x

Fukami, K., Yuzawa, A., Nishijima, T., and Hata, Y. (1992). Isolation and properties of a bacterium inhibiting the growth of Gymnodinium nagasakiense. Nippon Suisan Gakkaishi 58, 1073-1077. doi: 10.2331/suisan.58.1073

Gardes, A., Triana, C., Amin, S. A., Green, D. H., Romano, A., Trimble, L., et al. (2013). Detection of photoactive siderophore biosynthetic genes in the marine environment. Biometals 26, 507-516. doi: 10.1007/s10534-013-9635-1

Geng, H., and Belas, R. (2010). Molecular mechanisms underlying Roseobacterphytoplankton symbioses. Curr. Opin. Biotechnol. 21, 332-338. doi: 10.1016/j. copbio.2010.03.013

Green, D. H., Bowman, J. P., Smith, E. A., Gutierrez, T., and Bolch C. J. S. (2006). Marinobacter algicola sp. nov., isolated from laboratory cultures of paralytic shellfish toxin-producing dinoflagellates. Int. J. Syst. Evol. Microbiol. 56, 523-527. doi: 10.1099/ijs.0.63447-0

Green, D. H., Hart, M. C., Blackburn, S. I., and Bolch, C. J. S. (2010). Bacterial diversity of Gymnodinium catenatum and the relationship to dinoflagellate toxicity. Aquat. Microb. Ecol. 61, 73-87. doi: 10.3354/ame01437

Green, D. H., Llewellyn, L. E., Negri, A. P., Blackburn, S. I., and Bolch, C. J. S. (2004). Phylogenetic and functional diversity of the cultivable bacterial community associated with the paralytic shellfish poisoning dinoflagellate Gymnodinium catenatum. FEMS Microbiol. Ecol. 47, 345-357. doi: 10.1016/ S0168-6496(03)00298-8

Grossart, H. P. (1999). Interactions between marine bacteria and axenic diatoms (Cylindrotheca fusiformis, Nitzschia laevis, and Thalassiosira weissflogii) incubated under various conditions in the lab. Aquat. Microb. Ecol. 19, 1-11. doi: $10.3354 /$ ame 019001 
Guillard, R. R. L. (1973). “Division rates," in Handbook of Phycological Methods: Culture Methods and Growth Measurements, ed. J. R. Stein (London: Cambridge University), 289-312.

Guo, B., Gu, J., Ye, Y. G., Tan, Y. Q., Kida, K., and Wu, X. L. (2007). Marinobacter segnicrescens sp nov. a moderate halophile isolated from benthic sediment of the South China Sea. Int. J. Syst. Evol. Microbiol. 57, 1970-1974. doi: 10.1099/ ijs.0.65030-0

Hallegraeff, G. M., Blackburn, S. I., Doblin, M. A., and Bolch, C. J. S. (2012). Global toxicology, ecophysiology and population relationships of the chainforming PST dinoflagellate Gymnodinium catenatum. Harmful Algae 14, 130-143. doi: 10.1016/j.hal.2011.10.018

Hold, G. L., Smith, E. A., Birkbeck, T. H., and Gallacher, S. (2001). Comparison of paralytic shellfish toxin (PST) production by the dinoflagellates Alexandrium lusitanicum NEPCC 253 and Alexandrium tamarense NEPCC 407 in the presence and absence of bacteria. FEMS Microbiol. Ecol. 36, 223-234. doi: 10.1111/j.1574-6941.2001.tb00843.x

Iwata, Y., Sugahara, I., Kimura, T., Kowa, H., Matsumoto, A., and Noritake, K. (2004). Properties of an algicidal bacterium (Flavobacterium sp.) against Karenia mikimotoi isolated from Ise Bay, Japan. Nippon Suisan Gakkaishi 70, 537-541. doi: 10.2331/suisan.70.537

Jasti, S., Sieracki, M. E., Poulton, N. J., Giewat, M. W., and Rooney-Varga, J. N. (2005). Phylogenetic diversity and specificity of bacteria closely associated with Alexandrium sp. and other phytoplankton. Appl. Environ. Microbiol. 71, 3483-3494. doi: 10.1128/AEM.71.7.3483-3494.2005

Jeong, H. J., Yoo, Y. D., Park, J. Y., Song, J. Y., Kim, S. T., Lee, S. H., et al. (2005). Feeding by the phototrophic red-tide dinoflagellates: five species newly revealed and six species previously known to be mixotrophic. Aquat. Microb. Ecol. 40, 133-155. doi: 10.3354/ame040133

Jumars, P. A., Penry, D. L., Baross, J. A., Perry, M. J., and Frost, B. W. (1989). Closing the microbial loop: dissolved carbon pathway to heterotrophic bacteria from incomplete ingestion, digestion and absorption in animals. Deep Sea Res. 36, 483-495. doi: 10.1016/0198-0149(89)90001-0

Kiefer, D. A. (1973). Chlorophyll a fluorescence in marine centric diatoms: responses of chloroplasts to light and nutrient stress. Mar. Biol. 23, 39-46. doi: 10.1007/BF00394110

Lau, W. W. Y., Keil, R. G., and Armbrust, E. V. (2007). Succession and diel transcriptional response of the glycolate-utilizing component of the bacterial community during a spring phytoplankton bloom. Appl. Environ. Microbiol. 73, 2440-2450. doi: 10.1128/AEM.01965-06

Mayali, X., and Doucette, G. J. (2002). Microbial community interactions and population dynamics of an algicidal bacterium active against Karenia brevis (Dinophyceae). Harmful Algae 1, 277-293. doi: 10.1016/S1568-9883(02) 00032-X

Mayali, X., Franks, P. J. S., and Azam, F. (2007). Bacterial induction of temporary cyst formation by the dinoflagellate Lingulodinium polyedrum. Aquat. Microb. Ecol. 50, 51-62. doi: 10.3354/ame01143

Morel, F., and Hudson, R. (1985). "Geobiological cycle of trace elements in aquatic systems: redfield revisited," in Chemical Processes in Lakes, ed. W. Stumm (New York, NY: John Wiley and Sons), 251-281.

Osada, M., and Stewart, J. E. (1997). Gluconic acid gluconolactone: physiological influences on domoic acid production by bacteria associated with Pseudonitzschia multiseries. Aquat. Microb. Ecol. 12, 203-209. doi: 10.3354/ame 012203

Paul, C., and Pohnert, G. (2011). Interactions of the algicidal bacterium Kordia algicida with diatoms: regulated protease excretion for specific algal lysis. PLoS ONE 6:e21032. doi: 10.1371/journal.pone.0021032

Prieto, A., Barber-Lluch, E., Haernandez-Ruiz, M., Martinez-Garcia, S., Fernandez, E., and Tiera, E. (2015). Assessing the role of phytoplanktonbacterioplankton coupling in response the response of microbial plankton to nutrient additions. J. Plankton Res. 38, 55-63. doi: 10.1093/plankt/ fbv101

Ramanan, R., Kim, B.-H., Cho, D.-H., Oh, H.-M., and Kim, H.-S. (2015). Algaebacteria interactions: evolution, ecology and emerging applications. Biotechnol. Adv. 34, 14-29. doi: 10.1016/j.biotechadv.2015.12.003

Seibold, A., Wichels, A., and Schütt, C. (2001). Diversity of endocytic bacteria in the dinoflagellate Noctiluca scintillans. Aquat. Microb. Ecol. 25, 229-235. doi: 10.3354/ame025229

Seong, K. A., Jeong, H. J., Kim, S., Kim, G. H., and Kang, J. H. (2006). Bacterivory by co-occurring red-tide algae, heterotrophic nanoflagellates, and ciliates. Mar. Ecol. Prog. Ser. 322, 85-97. doi: 10.3354/meps322085

Seyedsayamdost, M. R., Case, R. J., Kolter, R., and Clardy, J. (2011). The Jekylland-Hyde chemistry of Phaeobacter gallaeciensis. Nat. Chem. 3, 331-335. doi: $10.1038 /$ nchem. 1002

Suminto, S., and Hirayama, K. (1997). Application of a growth promoting bacteria for stable mass culture of three marine microalgae. Hydrobiologia 358, 223-230. doi: 10.1023/A:1003109503745

Tanabe, Y., Okazaki, Y., Yoshida, M., Matsuura, H., Kai, A., Shiratori, T., et al. (2015). A novel alphaproteobacterial ectosymbiont promotes the growth of the hydrocarbon-rich green alga Botryococcus braunii. Sci. Rep. 5:10467. doi: $10.1038 /$ srep 10467

Thompson, P. (1999). Response of growth and biochemical composition to variations in daylength, temperature, and irradiance in the marine diatom Thalassiosira pseudonana (Bacillariophyceae). J. Phycol. 35, 1215-1223. doi: 10.1046/j.1529-8817.1999.3561215.x

Turner, J. T., Tester, P. A., and Hansen, P. J. (1998). "Intertactions between toxic marine phytoplanktion and metazoan and protistan grazers," in Physiological Ecology of Harmful Algal Blooms, eds D. M. Anderson, A. D. Cembella, and G. M. Hallegraeff (Berlin: Springer- Veralag), 453-474.

Veldhuis, M. J. W., Kraay, G. W., and Timmermans, K. R. (2001). Cell death in phytoplankton: correlation between changes in membrane permeability, photosynthetic activity, pigmentation and growth. Eur. J. Phycol. 36, 167-177. doi: 10.1080/09670260110001735318

Wang, H., Tomasch, J., Jarek, M., and Wagner-Döbler, I. (2014). A dualspecies co-cultivation system to study the interactions between Roseobacters and dinoflagellates. Front. Microbiol. 5:311. doi: 10.3389/fmicb.2014. 00311

Wang, H., Tomasch, J., Michael, V., Bhuju, S., Jarek, M., Petersen, J., et al. (2015). Identification of genetic modules mediating the Jekyll and Hyde interaction of Dinoroseobacter shibae with the dinoflagellate Prorocentrum minimum. Front. Microbiol. 6:1262. doi: 10.3389/fmicb.2015.01262

Wheeler, P. A., and Kirchman, D. L. (1986). Utilization of inorganic and organic nitrogen by bacteria in marine systems. Limnol. Oceanogr. 31, 998-1009. doi: 10.4319/lo.1986.31.5.0998

Wiebe, W. J., and Pomeroy, L. R. (1999). "The temperature-substrate controversy resolved?" in Microbial Biosystems: New Frontiers, Proceedings of the 8th International Symposium on Microbial Ecology, eds C. R. Bell, M. J. Brylinsky, and P. Johnson-Green (Halifax, NS).

Conflict of Interest Statement: The authors declare that the research was conducted in the absence of any commercial or financial relationships that could be construed as a potential conflict of interest.

Copyright (C) 2017 Bolch, Bejoy and Green. This is an open-access article distributed under the terms of the Creative Commons Attribution License (CC BY). The use, distribution or reproduction in other forums is permitted, provided the original author(s) or licensor are credited and that the original publication in this journal is cited, in accordance with accepted academic practice. No use, distribution or reproduction is permitted which does not comply with these terms. 